\title{
Prognostic significance of peripheral CD8+CD28+ and CD8+CD28-T cells in advanced non-small cell lung cancer patients treated with chemo(radio)therapy
}

\author{
Chao Liu ${ }^{1,2,3}$, Wang Jing ${ }^{2}$, Ning An ${ }^{2}$, Aijie Li ${ }^{4}$, Weiwei Yan ${ }^{2}$, Hui Zhu ${ }^{2^{*}}$ and Jinming $\mathrm{Yu}^{1,2^{*}}$
}

\begin{abstract}
Background: Noninvasive prognostic biomarkers are needed for advanced non-small cell lung cancer (NSCLC) patients with different histological types to identify cases with poor survival. Here, we investigated the prognostic values of peripheral CD8+CD28+ T cells and CD8+CD28- T cells in advanced NSCLC patients treated with chemo(radio)therapy and the impact of histological type on them.
\end{abstract}

Methods: Of 232 registered advanced NSCLC patients, 101 treatment-naïve individuals were eligible and included in our study. Flow cytometry was used to evaluate CD8+CD28+T cells, CD8+CD28-T cells, CD4+ CD25 hi T cells, B cells, natural killer cells, $ү \delta T$ cells, and natural killer T cells in patients' peripheral blood.

Results: The median follow-up time was 13.6 months. Fifty-nine (58.4\%) patients died by the end of our study. Fiftythree of the 101 advanced NSCLC cases selected for our study were adenocarcinomas (ADs), and 48 were squamous cell carcinomas (SCCs). Multivariate analyses showed that increased levels of CD8+CD28+T cells independently predicted favorable overall survival (OS) [hazard ratio (HR): 0.51, 95\% confidence interval (Cl) $0.30-0.89, \mathrm{P}=0.021$ ] and progression-free survival (PFS) (HR: $0.66,95 \% \mathrm{Cl} 0.37-0.93, \mathrm{P}=0.038)$ in $\mathrm{ADs}$, but the prediction in SCCs was not statistically significant. In contrast, high levels of CD8+CD28- T cells independently predicted unfavorable OS (HR: $1.41,95 \% \mathrm{Cl} 1.17-3.06, \mathrm{P}=0.035)$ and PFS (HR: 2.01, 95\% Cl 1.06-3.85, $\mathrm{P}=0.029)$ in SCCs, but the prediction in ADs was not statistically significant. ADs had higher levels of CD4+CD25 hi T cells and CD8+CD28- T cells and lower NK cells (all $\mathrm{P}<0.05$ ) than SCCs.

Conclusions: Our findings uncovered the prognostic values of peripheral CD8+CD28+ T cells and CD8+CD28- T cells in advanced NSCLC patients treated with chemo(radio)therapy, which could help to identify patients with poor outcomes and refine treatment strategies.

Keywords: CD28, Prognostic value, Squamous cell carcinoma, Adenocarcinoma, Peripheral blood

\section{Background}

Among all lung cancer patients, more than $80 \%$ of patients have non-small cell lung cancer (NSCLC), which mainly consists of adenocarcinomas (ADs) and squamous cell carcinomas (SCCs) [1, 2]. Chemo(radio)

\footnotetext{
*Correspondence: drzhuh@126.com; sdyujinming@163.com ${ }^{2}$ Department of Radiation Oncology, Shandong Cancer Hospital and Institute, Shandong First Medical University and Shandong Academy of Medical Sciences, Jinan 250117, Shandong, China

Full list of author information is available at the end of the article
}

therapy is the standard treatment for advanced NSCLC patients [3-5]. These advanced patients have diverse clinical outcomes [5]. Consequently, prognostic markers are needed to identify patients with poor outcomes and refine the treatment strategies for them. To date, some prognostic markers were investigated in advanced NSCLC, including positron emission tomography parameters, driver gene mutation, number of metastatic sites, interleukin-6, cell-free DNA, circulating tumor cells, inflammation parameters, and 
tumor-infiltrating lymphocytes (TILs) [6-16]. More noninvasive prognostic biomarkers are needed for advanced NSCLC patients with different histological types to identify cases with poor survival.

Several studies have revealed the differences in the expression of genes, methylation, and tumor immune microenvironment between lung AD and SCC [6, 17-21]. Faruki et al. [19] reported major differences in the tumor immune landscapes of the expression subtypes of lung $\mathrm{AD}$ and $\mathrm{SCC}$. The immune cell expression of the proximal proliferative subtype (with serine/threonine kinase 11 (STK11) gene deletion, poor prognosis, and high proliferation) was low among ADs, whereas, the immune cell expression of the secretory subtype (with the genomic data of greater inflammatory response) was high among SCCs. Per Kinoshita et al. [6], different prognostic roles are played by TILs in AD and non-AD. Specifically, they identified a high ratio of forkhead box P3+ (FOXP3+) to $\mathrm{CD} 4+\mathrm{T}$ cells and a low buildup of $\mathrm{CD} 20+\mathrm{B}$ cells as worse factors of prognosis in AD patients. Fewer CD8+ $\mathrm{T}$ cells correlated with a negative outcome in non-AD. Thus, the histological type could impact the immune cells' prognostic role in NSCLC.

Despite this advanced knowledge, the effect of histological type on the prognostic role of peripheral immune cells, collected by a rapid and noninvasive method, remains to be clarified. The anti-tumor effect of CD8+ $\mathrm{T}$ cells requires the activation of two co-stimulatory signals. Firstly, $\mathrm{T}$ cell receptors on $\mathrm{CD} 8+\mathrm{T}$ cells recognize and combine with tumor antigens presented by antigenpresenting cells (APCs). Secondly, CD28, as another significant signal on CD8 $+\mathrm{T}$ cells, combines with B7 molecules on APCs. T cells are activated and exert immune responses to tumors when both signals are engaged [22, 23]. However, CD28 expression in CD8+ T cells may be down-regulated in patients with tumors because of tumor antigens' chronic stimulation [24]. Finally, CD8+ T cells are less responsive to tumor antigens and lose control of tumor cells in cancer patients [24, 25].

Our previous study suggested that tumor progression in NSCLC patients undergoing radiotherapy could be predicted independently by peripheral regulatory $\mathrm{T}$ cells [26]. In this present study, we aimed to further clarify peripheral immune prognostic factors, especially for CD8+CD28+ T cells and CD8+CD28- T cells, in advanced lung ADs and SCCs.

\section{Methods}

\section{Patients}

Clinical stage III and IV patients with histologically confirmed NSCLC were selected for this study. Patients with targetable oncogenes [including anaplastic lymphoma kinase (ALK), epidermal growth factor receptor (EGFR),
cMET, and Ki-ras (KRAS)] were excluded, as well as were patients with incomplete clinicopathological data, performance status (PS) $>2$, hematological, renal, and liver diseases, general infection, and other tumors, and those who received immune-related drugs, including granulocyte-colony stimulating factor, steroids, and antilymphocyte globulin, during the 3 months preceding enrollment. Of 232 advanced NSCLC patients enrolled between April 2014 and April 2017, 101 treatment-naïve patients were eligible and included in our study. Fifty-eight age- and sex-matched healthy volunteers were chosen as control.

\section{Flow cytometry}

Four milliliters of fresh blood were collected from healthy volunteers and patients during the 3 days preceding any anti-tumor treatments (chemo/radiation/immunotherapy/surgery) and stored in EDTA in anti-coagulant tubes. Peripheral leucocytes were stained with surface markers using the following specific anti-human monoclonal antibodies for $15 \mathrm{~min}$ in the dark, at room temperature: CD8 FITC, CD28 PE, CD45 PerCP, CD3 APC, CD4 FITC, CD25 APC, CD3 FITC, CD16+CD56 PE, CD19 APC, and $\gamma \delta$ T Cell Receptor (TCR) PE to identify seven lymphocytes subsets: B cells (CD3-CD19+), natural killer $(\mathrm{NK})$ cells $[\mathrm{CD} 3-(\mathrm{CD} 16+56+)], \gamma \delta \mathrm{T}$ cells $(\mathrm{CD} 3+\gamma \delta \mathrm{TCR}+), \quad \mathrm{NKT}$ cells $[\mathrm{CD} 3+(\mathrm{CD} 16+56+)]$, CD $4+C D 25^{\text {hi }}$ T cells $\left(\mathrm{CD} 4+\mathrm{CD} 25^{\mathrm{hi}}\right), \mathrm{CD} 8+\mathrm{CD} 28-\mathrm{T}$ cells $(\mathrm{CD} 3+\mathrm{CD} 8+\mathrm{CD} 28-)$, and $\mathrm{CD} 8+\mathrm{CD} 28+\mathrm{T}$ cells (CD3+CD8+CD28+).

Next, red blood cell lysis was performed with Red Blood Cell lysing buffer (BD Biosciences; USA) for $10 \mathrm{~min}$ in the dark, at room temperature, followed by flow cytometry (BD Biosciences; USA) for the analysis of residual white blood cells. We used the FlowJo Version 10 data analysis software (FlowJo, Ashland, OR, USA) to determine the frequency of total lymphocytes for each lymphocyte subset. Representative figures showing the gating of each population are presented in Additional file 1: Figure S1.

\section{Data collection, treatment, and follow-up}

We collected information on the stage of the disease, histology, tumor differentiation, smoking status, gender, age, and performance status as per the American Joint Committee on Cancer (AJCC-7 criteria [27]). Every patient was treated with cisplatin-based chemotherapy for 4-6 cycles. Among 75 stage IV patients, 11 received consolidated radiotherapy $(60-66$ Gy/30-33 fractions or $50 \mathrm{~Gy} / 5$ fractions) for lung lesions after chemotherapy. Stage III patients were subjected to concurrent chemoradiotherapy (60-66 Gy/30-33 fractions). Follow-up was performed regularly every 3 months and ended in October 2018. 


\section{Statistical analysis}

Cut-off values (high vs. low) of every immune cell were determined using the median values of the cells. In subgroup analyses, the median values of each group were used to determine cut-off values. Continuous parameters were presented as mean \pm standard deviation. We used the Student's t-test to compare immune cells between two groups. Univariate and multivariate Cox proportional hazards regression models were used for the evaluation of hazard ratios (HRs). Univariate-analyzed variables with $P<0.010$ were examined further using multivariate analytics. The area under the receiver operating characteristic curve was used to evaluate immune cells' predictive ability for patients' survival. We defined PFS as the period from patient enrollment to disease relapse, tumor metastasis, death, or end or loss of follow-up. OS represented the time between patient enrollment and death, or end or loss of follow-up. We utilized the Kaplan-Meier curve for the estimation of patient survival. The log-rank test was use to compare survival between groups. The SPSS 23.0 software was used for Data analysis (SPSS Inc., Chicago, IL). We considered a $P$-value $<0.05$ statistically significant.

\section{Results}

\section{Demographics}

The characteristics of the 101 advanced NSCLC patients enrolled in this study are shown in Additional file 2: Table S1. Among them, 42 patients were $<60$ years old, and 59 were $\geq 60$ years old; 65 were males, and 36 were females; 53 were ADs, and 48 were SCCs; 43 were non-smokers, and 58 were smokers; 26 were stage III, and 75 were stage IV; 30 were PS 0 , 66 were PS 1 , and 5 were PS 2 . The median follow-up period amounted to 13.6 months, at the end of which 59 (58.4\%) patients had died, and one patient had lost follow-up.

\section{Lymphocytes subsets and their prognostic value in 101 NSCLC cases}

The median count of the total lymphocytes in 101 NSCLC patients was $1.39(0.52-3.83) \times 10^{9} / \mathrm{L}$. Figure 1 shows how lymphocytes subsets compare between patients with NSCLC and healthy volunteers, male and female, ADs and SCCs, stage III and stage IV, smokers and non-smokers, age $<60$ and age $\geq 60$, and PS 0 and PS 1-2. According to the results, NSCLC patients had lower CD8+CD28+ $\mathrm{T}$ cells and B cells (both $\mathrm{P}<0.01)$ and slightly higher $\mathrm{CD} 4+\mathrm{CD} 25^{\text {hi }} \mathrm{T}$ cells, higher CD8+CD28 - T cells, and NK cells (all $\mathrm{P}<0.05)$ than healthy volunteers; ADs had slightly higher $\mathrm{CD} 4+\mathrm{CD} 25^{\text {hi }}$ $\mathrm{T}$ cells, higher CD8+CD28- T cells and lower NK cells (all $\mathrm{P}<0.05$ ) than $\mathrm{SCCs}$; stage IV patients had higher $\mathrm{CD} 4+\mathrm{CD} 25^{\text {hi }} \mathrm{T}$ cells and $\mathrm{CD} 8+\mathrm{CD} 28-\mathrm{T}$ cells than stage III patients (both $\mathrm{P}<0.05$ ); female patients had lower CD8+CD28 - T cells and higher B cells than male patients (both $\mathrm{P}<0.05$ ); and smokers had lower $\mathrm{B}$ cells and higher $\mathrm{CD} 8+\mathrm{CD} 28+\mathrm{T}$ cells than non-smokers (both $\mathrm{P}<0.05$ ).

Additional file 1: Figure S2 shows the distribution and median values of lymphocytes subsets in 101 NSCLC patients. The median values of $\mathrm{CD} 8+\mathrm{CD} 28+\mathrm{T}$ cells, CD8+CD28- T cells, B cells, NK cells, NKT cells, $\gamma \delta \mathrm{T}$ cells, CD4+CD25 ${ }^{\text {hi }} \mathrm{T}$ cells, and CD28+/CD28- ratios were 12.3 (6.1-28.4), 14.2 (3.3-42.9), 6.8 (1.6-25.6), 21.2 (3.2-53.6), 5.2 (1.0-26.3), 3.4 (0.3-42.8), $2.0(0.4-10.0)$, and $0.9(0.2-5.1)$, respectively. The Kaplan-Meier analysis was used to compare the OS and PFS of patients with high and low levels of immune cells and revealed no statistical difference of significance in the OS and PFS between groups (all $\mathrm{P}>0.05$ ), as shown in Fig. 2 and Additional file 1: Figure S3.

\section{The favorable prognostic role of high levels of $\mathrm{CD} 8+\mathrm{CD} 28+\mathrm{T}$ cells in $\mathrm{ADs}$}

The Kaplan-Meier analysis showed that ADs with high CD8+CD28 + $\mathrm{T}$ cells had better OS and PFS than ADs with low $\mathrm{CD} 8+\mathrm{CD} 28+\mathrm{T}$ cells $(\mathrm{P}=0.010$ and 0.020 , respectively, Fig. 3). In addition, ADs with high CD4+CD25 hi $\mathrm{T}$ cells had worse PFS than ADs with low $\mathrm{CD} 4+\mathrm{CD} 25^{\text {hi }} \mathrm{T}$ cells $(\mathrm{P}=0.017$, Fig. 3$)$. The univariate analyses for the survival of ADs revealed that high levels of CD8+CD28+ T cells predicted favorable OS (HR: 0.52 , 95\% CI 0.25-0.92, $\mathrm{P}=0.013$, Table 1) and PFS (HR: $0.59,95 \%$ CI $0.29-0.96, P=0.016$, Table 1$)$. Furthermore, increased levels of $\mathrm{CD} 4+\mathrm{CD} 25^{\mathrm{hi}} \mathrm{T}$ cells predicted an unfavorable PFS (HR: 1.96, 95\% CI 1.22-2.81, P $=0.011$, Table 1). Other immune cells did not correlate significantly with survival in our study (Additional file 1: Figure S4, Table 1).

According to multivariate analysis findings, high levels of $\mathrm{CD} 8+\mathrm{CD} 28+\mathrm{T}$ cells independently predicted favorable OS (HR: $0.51,95 \%$ CI $0.30-0.89, \mathrm{P}=0.021$, Table 1) and PFS (HR: 0.66, 95\% CI 0.37-0.93, $\mathrm{P}=0.038$, Table 1) in ADs. The areas under receiver operating characteristic curves (AUCs) were estimated for risk models with only CD8+CD28+ T cells for OS and PFS in ADs were 0.687 and 0.655 , respectively. Also, high $\mathrm{CD} 4+\mathrm{CD} 25^{\text {hi }} \mathrm{T}$ cells independently predicted an unfavorable PFS (HR: 1.53, 95\% CI 1.19-1.97, $\mathrm{P}=0.031$, Table 1).

\section{The unfavorable prognostic role of increased levels of CD8+CD28- T cells in SCCs}

The Kaplan-Meier analysis showed that SCCs with high CD8+CD28 - T cells had worse OS and PFS than 

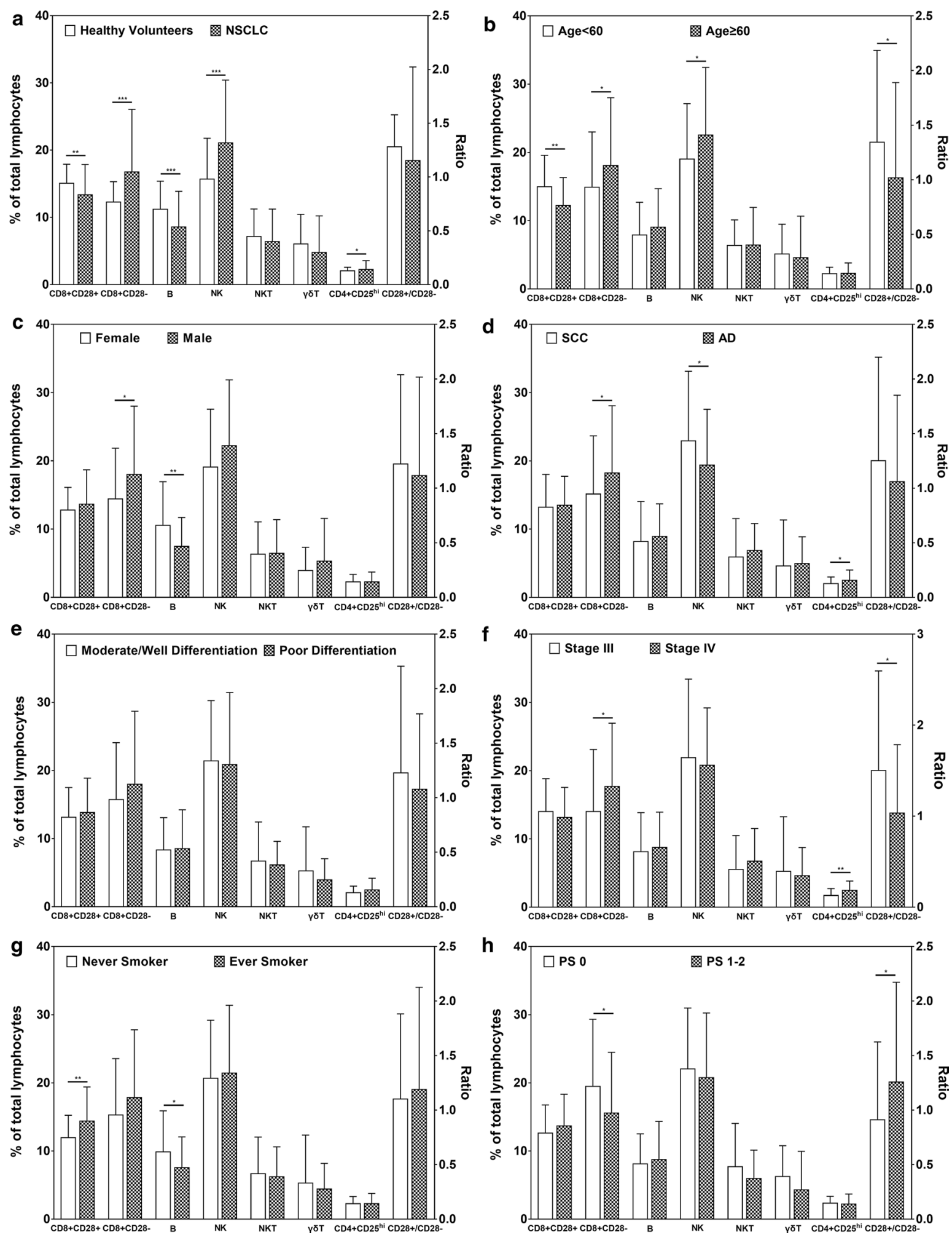

Fig. 1 Comparing subsets of peripheral lymphocytes between patients with a advanced NSCLC and healthy volunteers, $\mathbf{b}$ age $<60$ and age $\geq 60$, $\mathbf{c}$ male and female, $\mathbf{d}$ ADs and SCCS, e well/moderate differentiation and poor differentiation, $\mathbf{f}$ stage III and stage IV, $\mathbf{g}$ ever smokers and never smokers, and $\mathbf{h}$ PS 0 and PS 1-2. Data are presented as mean \pm SD. The Student's t-test was used for comparison of immune cells between two groups. ${ }^{*} \mathrm{P}<0.05,{ }^{* *} \mathrm{P}<0.01$, ${ }^{* *} \mathrm{P}<0.001$ 

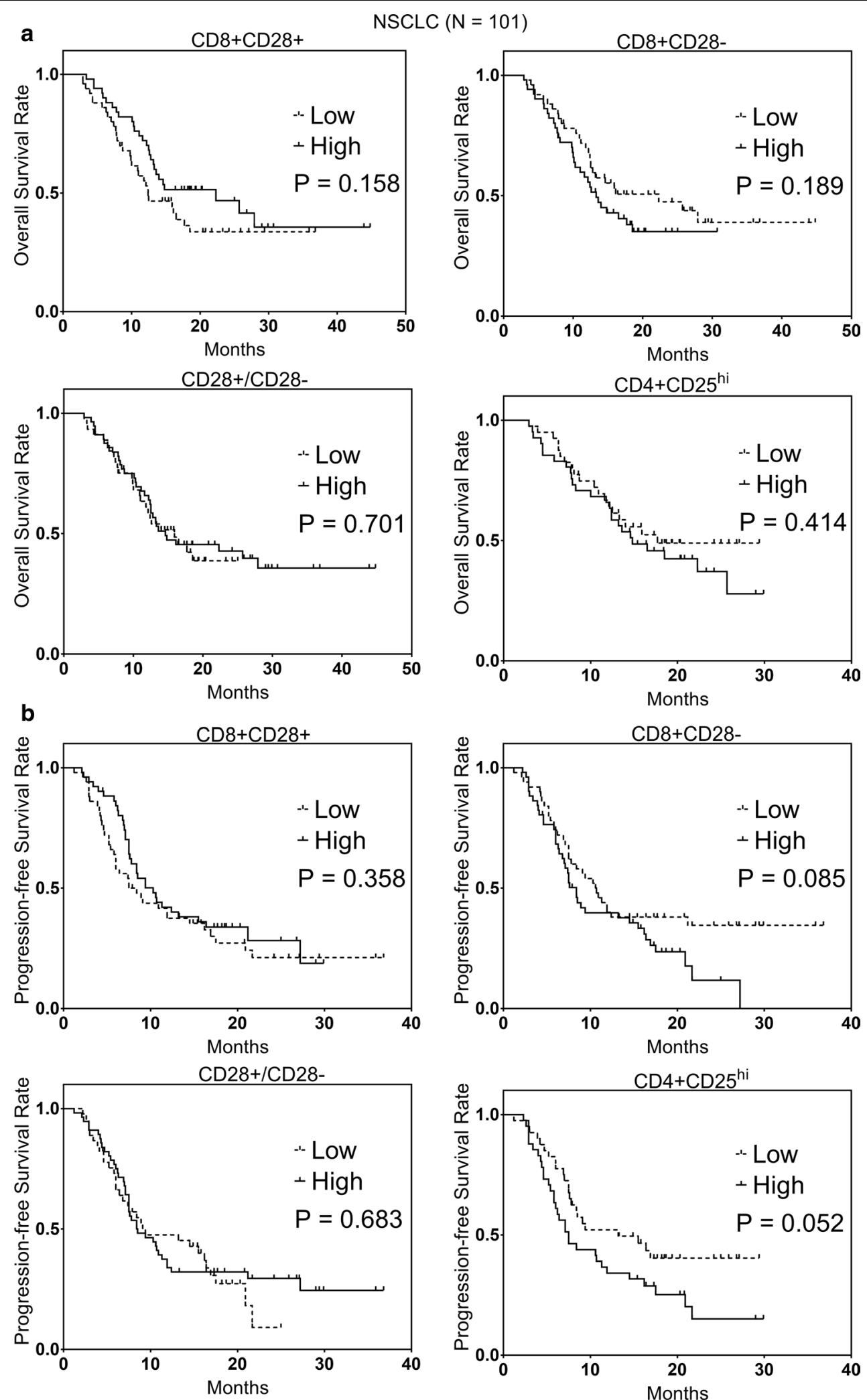

Fig. 2 The Kaplan-Meier representation of a OS and $\mathbf{b}$ PFS between high and low levels of CD8+CD28- T cells, CD8+CD28+T cells, CD28+/ CD28 - ratio, and CD4+CD25 hi T cells in 101 patients with advanced NSCLC 


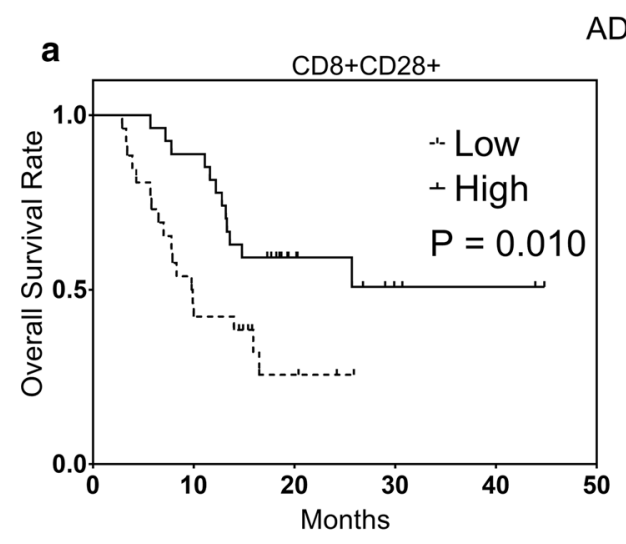

ADs $(N=53)$
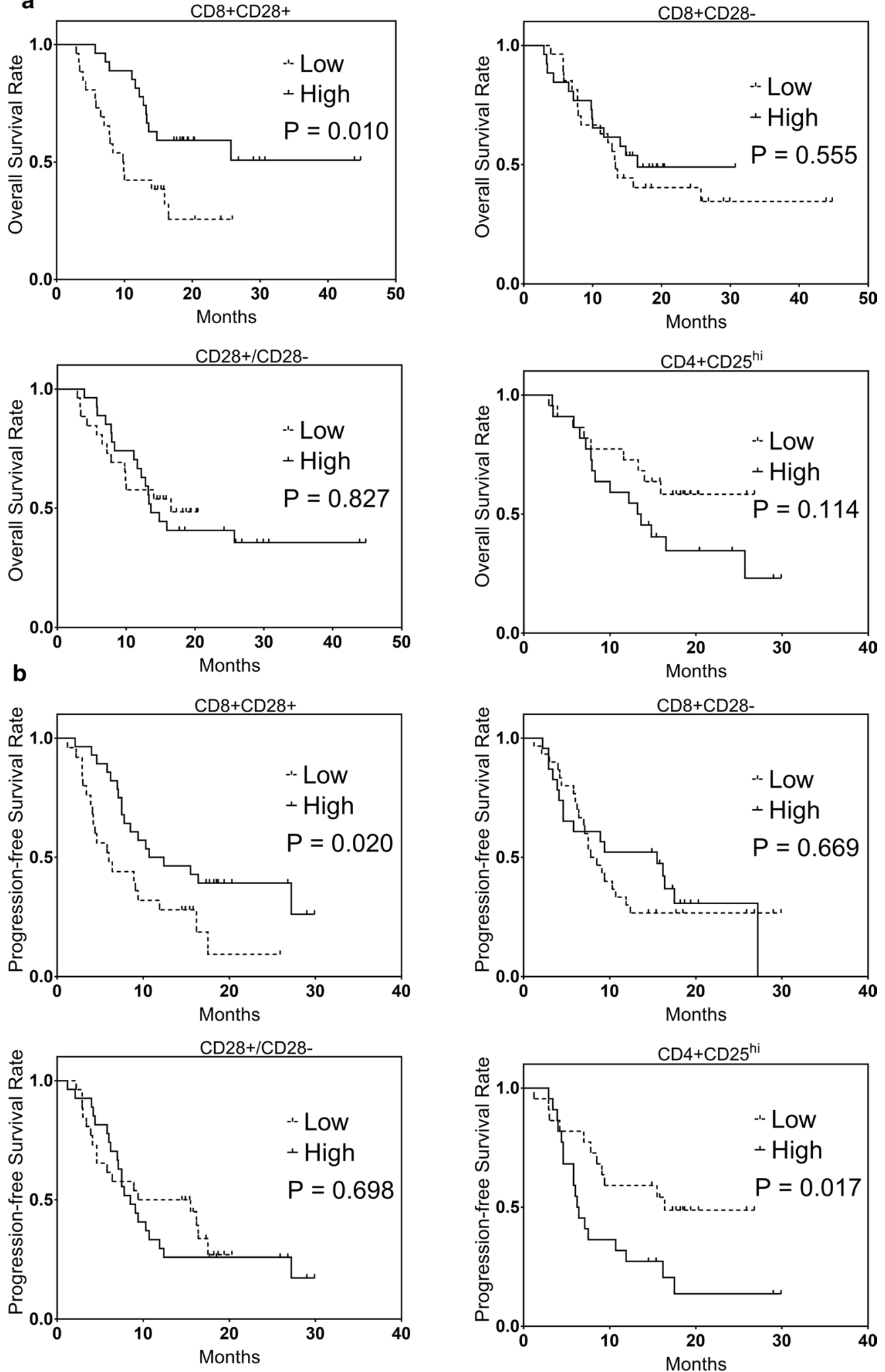

Fig. 3 The Kaplan-Meier representation of $\mathbf{a}$ OS and $\mathbf{b}$ PFS between high and low levels of CD8+CD28-T cells, CD8+CD28+T cells, CD28+/ CD28 - ratio, and CD4+CD25 ${ }^{\text {hi }} \mathrm{T}$ cells in 53 ADs 
Table 1 Univariate and multivariate analyses for survival of adenocarcinoma patients

\begin{tabular}{|c|c|c|c|c|}
\hline \multirow[t]{2}{*}{ Variables } & \multicolumn{2}{|l|}{ Overall survival } & \multicolumn{2}{|l|}{$\begin{array}{l}\text { Progression-free } \\
\text { survival }\end{array}$} \\
\hline & HR $(95 \% \mathrm{Cl})$ & $\mathbf{P}$ & $\mathrm{HR}(95 \% \mathrm{Cl})$ & $\mathbf{P}$ \\
\hline \multicolumn{5}{|l|}{ A (univariate) } \\
\hline \multicolumn{5}{|l|}{ Gender } \\
\hline Male & $1.88(0.89-3.97)$ & 0.094 & $2.16(1.10-4.23)$ & 0.025 \\
\hline Female & 1 & & 1 & \\
\hline \multicolumn{5}{|l|}{ Age (years) } \\
\hline$\geq 60$ & $1.23(0.60-2.54)$ & 0.565 & $1.12(0.58-2.13)$ & 0.731 \\
\hline$<60$ & 1 & & 1 & \\
\hline \multicolumn{5}{|l|}{ Smoking status } \\
\hline Ever smokers & $1.73(0.84-3.55)$ & 0.136 & $1.60(0.84-3.04)$ & 0.147 \\
\hline Never smokers & 1 & & 1 & \\
\hline \multicolumn{5}{|l|}{ cStage } \\
\hline IV & $1.05(0.25-4.45)$ & 0.940 & $0.76(0.23-2.49)$ & 0.658 \\
\hline III & 1 & & 1 & \\
\hline \multicolumn{5}{|c|}{ Tumor differentiation } \\
\hline Poor & $1.90(0.88-4.11)$ & 0.101 & $1.75(0.89-3.45)$ & 0.103 \\
\hline Well/moderate & 1 & & 1 & \\
\hline \multicolumn{5}{|c|}{ Performance status } \\
\hline $1-2$ & $1.68(0.64-4.41)$ & 0.291 & $1.97(0.82-4.73)$ & 0.129 \\
\hline 0 & 1 & & 1 & \\
\hline B & $0.99(0.92-1.07)$ & 0.818 & $0.93(0.86-1.06)$ & 0.677 \\
\hline NK & $1.01(0.96-1.05)$ & 0.892 & $0.96(0.91-1.02)$ & 0.645 \\
\hline NKT & $0.87(0.58-1.09)$ & 0.583 & $0.68(0.36-1.07)$ & 0.328 \\
\hline$\gamma \delta \mathrm{T}$ & $0.94(0.85-1.05)$ & 0.298 & $0.95(0.86-1.04)$ & 0.295 \\
\hline CD8+CD28+ & $0.52(0.25-0.92)$ & 0.013 & $0.59(0.29-0.96)$ & 0.016 \\
\hline CD8+CD28- & $0.93(0.79-1.12)$ & 0.349 & $0.98(0.95-1.02)$ & 0.314 \\
\hline CD28+/CD28- & $1.08(0.69-1.68)$ & 0.735 & $1.00(0.68-1.47)$ & 0.991 \\
\hline $\mathrm{CD} 4+\mathrm{CD} 25^{\mathrm{hi}}$ & $1.57(0.88-2.46)$ & 0.153 & $1.96(1.22-2.81)$ & 0.011 \\
\hline \multicolumn{5}{|l|}{ B (multivariate) } \\
\hline Gender & $1.92(0.82-4.49)$ & 0.133 & $2.12(0.99-4.57)$ & 0.055 \\
\hline CD8+CD28+ & $0.51(0.30-0.89)$ & 0.021 & $0.66(0.37-0.93)$ & 0.038 \\
\hline $\mathrm{CD} 4+\mathrm{CD} 25^{\mathrm{hi}}$ & - & - & $1.53(1.19-1.97)$ & 0.031 \\
\hline
\end{tabular}

P-values for multivariate analyses are adjusted. The $\mathrm{HR}$ and $95 \% \mathrm{Cl}$ were reported for $1 \mathrm{SD}$ increase for immune cells

SCCs with low CD8+CD28- T cells $(\mathrm{P}=0.035$ and 0.017 , respectively, Fig. 4). Results from univariate analyses showed that high CD8+CD28- T cells predicted unfavorable OS (HR: 2.01, 95\% CI 1.16-4.05, $\mathrm{P}=0.039$, Table 2) and PFS (HR: 2.12, 95\% CI 1.07-4.36, $\mathrm{P}=0.023$, Table 2). No other immune cells were found to be linked significantly to survival in our study (Additional file 1: Figure S5, Table 2).

Per multivariate analyses findings, CD8+CD28- T cells independently predicted unfavorable OS (HR: 1.41, $95 \%$ CI $1.17-3.06, \mathrm{P}=0.035$, Table 2) and PFS (HR: 2.01, $95 \%$ CI $1.06-3.85, P=0.029$, Table 2 ) in SCCs. AUCs were estimated for risk models with only CD8+CD28$\mathrm{T}$ cells for OS and PFS in SCCs were 0.689 and 0.713, respectively.

\section{Discussion}

A previous investigation showed already that the prognostic value of TILs fluctuates depending on the histological type [6]. Here, we present additional information on this issue in terms of peripheral lymphocytes subsets. High levels of peripheral CD8+CD28+ T cells presented favorable prognosis in ADs. Moreover, increased levels of CD8+CD28 - T cells independently predicted poor survival in SCCs. ADs also exhibited higher CD4+CD $25^{\text {hi }} \mathrm{T}$ cells and CD8+CD28 - T cells and lower NK cells than SCCs.

In NSCLC, higher peripheral CD8+CD28- T cells, CD4+CD25+FOXP3+ regulatory $\mathrm{T}$ cells, CTLA-4+ cells (in both $\mathrm{CD} 4+$ and $\mathrm{CD} 8+\mathrm{T}$ cells), proliferating CD8(+) $\mathrm{T}$ cells, and lower CD4+T cells and CD4/CD8 ratios have been observed when compared with healthy controls [26, 28-30]. Fewer CD8+ and CD4+ tumor infiltrating lymphocytes (TILs) were found within tumor cell clusters when compared with the stromal compartment in NSCLC [31]. TILs and tumor-infiltrating regulatory $\mathrm{T}$ cells were detected in $83 \%$ and $51 \%$, respectively, of early-stage NSCLC patients [32].

Song et al. [33] revealed that high levels of peripheral CD8+CD28+T cells are linked to prolonged PFS, whereas high CD8+CD28- T cells correlate with shortening PFS in metastatic breast cancer patients. Additionally, the same investigation reported increased CD8+CD28 - T cells and CD4+CD25 ${ }^{\text {hi }} \mathrm{T}$ cells and decreased $\mathrm{CD} 8+\mathrm{CD} 28+\mathrm{T}$ cells in metastatic breast cancer patients when compared with healthy volunteers. Another study reported increased CD8+CD28- T cells and CD4+CD25 ${ }^{\text {hi }} \mathrm{T}$ cells in advanced lung cancer patients [29]. Consistent with these investigations, we now report similar results in advanced NSCLC.

Although our results are similar to those of previous findings, those studies did not examine the prognostic values of immune cells in NSCLC. Most evaluations have centered primarily on the role of $\mathrm{CD} 8+\mathrm{T}$ cells in peripheral blood and the tumor microenvironment in various tumors, with no further classification of CD28 cells into CD28+ and CD28- subgroups [30, 31, 34-40]. CD28 is a co-stimulatory molecule that is important for the activation of $\mathrm{CD} 8+\mathrm{T}$ cells, which play an important role in anti-tumor immunity [41-44]. Recent studies have also proven that PD-1-targeted therapies' salvaging of exhausted CD8 T cells depends on CD28 [43]. On the contrary, the loss of expression of CD28 leads to CD8 T 


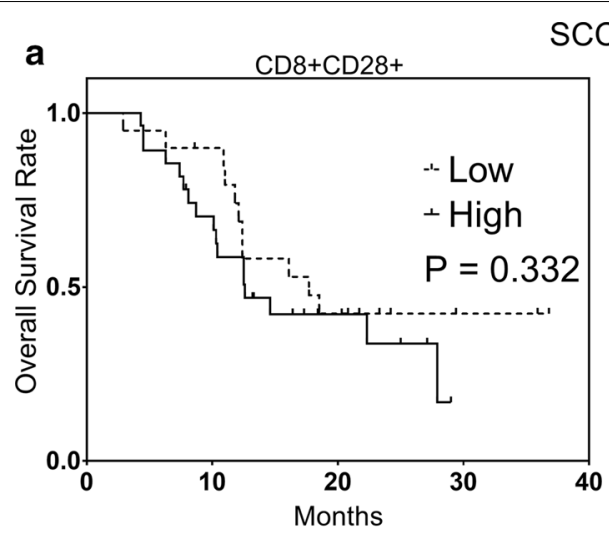

$\operatorname{SCCs}(N=48)$
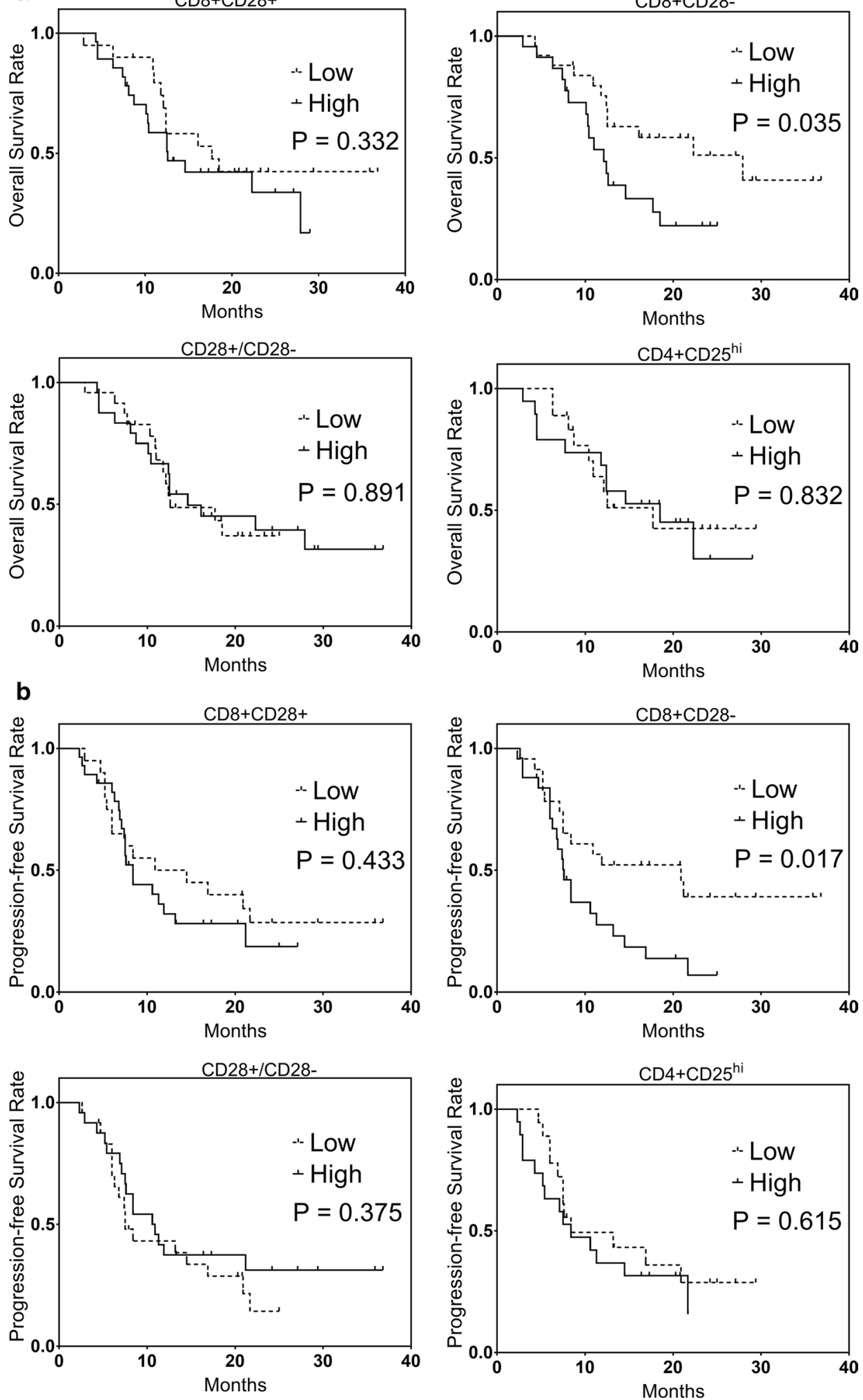

Fig. 4 The Kaplan-Meier representation of a OS and b PFS between high and low levels of CD8+CD28-T cells, CD8+CD28+T cells, CD28+/ CD28- ratio, and CD4+CD25 ${ }^{\text {hi }} T$ cells in 48 SCCs 
Table 2 Univariate and multivariate analyses for survival of squamous cell carcinoma patients

\begin{tabular}{|c|c|c|c|c|}
\hline \multirow[t]{2}{*}{ Variables } & \multicolumn{2}{|l|}{ Overall survival } & \multicolumn{2}{|c|}{$\begin{array}{l}\text { Progression-free } \\
\text { survival }\end{array}$} \\
\hline & HR $(95 \% \mathrm{Cl})$ & $\mathbf{P}$ & $\mathrm{HR}(95 \% \mathrm{Cl})$ & $\mathbf{P}$ \\
\hline \multicolumn{5}{|l|}{ A (univariate) } \\
\hline \multicolumn{5}{|l|}{ Gender } \\
\hline Male & $1.50(0.56-3.96)$ & 0.414 & $0.97(0.42-2.25)$ & 0.954 \\
\hline Female & 1 & & 1 & \\
\hline \multicolumn{5}{|l|}{ Age (years) } \\
\hline$\geq 60$ & $0.47(0.21-1.05)$ & 0.069 & $0.49(0.23-1.04)$ & 0.065 \\
\hline$<60$ & 1 & & 1 & \\
\hline \multicolumn{5}{|l|}{ Smoking status } \\
\hline Ever smokers & $1.08(0.46-2.56)$ & 0.852 & $0.81(0.37-1.73)$ & 0.581 \\
\hline Never smokers & 1 & & 1 & \\
\hline \multicolumn{5}{|l|}{ cStage } \\
\hline IV & $1.22(0.58-2.56)$ & 0.597 & $1.15(0.58-2.27)$ & 0.681 \\
\hline III & 1 & & 1 & \\
\hline \multicolumn{5}{|c|}{ Tumor differentiation } \\
\hline Poor & $1.30(0.58-2.91)$ & 0.52 & $1.29(0.60-2.75)$ & 0.512 \\
\hline Well/moderate & 1 & & 1 & \\
\hline \multicolumn{5}{|c|}{ Performance status } \\
\hline $1-2$ & $1.72(0.72-4.06)$ & 0.215 & $1.30(0.63-2.68)$ & 0.471 \\
\hline 0 & 1 & & 1 & \\
\hline B & $1.29(0.91-2.03)$ & 0.328 & $1.17(0.96-1.82)$ & 0.532 \\
\hline NK & $0.97(0.57-1.82)$ & 0.165 & $0.92(0.62-1.56)$ & 0.181 \\
\hline NKT & $1.19(0.73-1.65)$ & 0.720 & $1.21(0.86-1.76)$ & 0.824 \\
\hline$\gamma \delta T$ & $0.65(0.35-1.36)$ & 0.611 & $0.78(0.43-1.44)$ & 0.955 \\
\hline $\mathrm{CD} 8+\mathrm{CD} 28+$ & $1.01(0.94-1.10)$ & 0.749 & $0.99(0.93-1.07)$ & 0.902 \\
\hline CD8+CD28- & $2.01(1.16-4.05)$ & 0.039 & $2.12(1.07-4.36)$ & 0.023 \\
\hline CD28+/CD28- & $0.96(0.68-1.37)$ & 0.863 & $0.87(0.61-1.22)$ & 0.414 \\
\hline CD4+CD25 $5^{\text {hi }}$ & $1.17(0.68-2.04)$ & 0.570 & $1.28(0.78-2.10)$ & 0.331 \\
\hline \multicolumn{5}{|l|}{ B (multivariate) } \\
\hline Age (years) & $0.47(0.21-1.05)$ & 0.064 & $0.48(0.22-1.02)$ & 0.057 \\
\hline $\mathrm{CD} 8+\mathrm{CD} 28-$ & $1.41(1.17-3.06)$ & 0.035 & $2.01(1.06-3.85)$ & 0.029 \\
\hline
\end{tabular}

$\mathrm{P}$-values for multivariate analyses are adjusted. The $\mathrm{HR}$ and $95 \% \mathrm{Cl}$ were reported for $1 \mathrm{SD}$ increase for immune cells

cells losing their cytotoxic function and inhibiting the proliferation of $\mathrm{T}$ cells [44]. Hence, we speculated that CD28 expression in CD8+T cells influences their antitumor immune response in NSCLC patients, and, consequently, impact patients' survival.

To the best of our knowledge, our study is the first to report the prognostic value of peripheral $\mathrm{CD} 8+\mathrm{CD} 28+$ $\mathrm{T}$ cells and CD8+CD28- $\mathrm{T}$ cells in advanced NSCLC based on histological types. We showed the existing correlation between increased peripheral $\mathrm{CD} 8+\mathrm{CD} 28+\mathrm{T}$ cells and prolonged survival in ADs, which is consistent with the anti-tumor function of CD8+CD28+ T cells [22, 45]. We demonstrated further that high CD8+CD28- T cells predicted an unfavorable survival in SCCs, which may because of the loss of CD28 on CD8+ T cells and consequent inhibitory effect of them [46]. However, we found that the prognostic value of CD8+CD28+ T cells in SCCs and CD8+CD28- T cells in ADs did not reach statistical significance, which may have arisen from the differences in tumor immunity, gene expression, and methylation between ADs and SCCs [6, 17-20].

Although our study produced promising results, it still has its limitations. Firstly, although diseases that could impact peripheral immune cells were excluded, some undetected or unreported ailments could have slipped through our selection criterion. Secondly, patients' systematic immune functioning could have been influenced by their daily eating, activity, and sleeping. Thirdly, the sample size of our investigation was relatively small. Finally, different $\mathrm{p}$-values may have resulted from the different high/low stratification of immune cells and different patients between ADs and SCCs. Thus, a larger and more uniform patient cohort should potentially validate these results.

\section{Conclusions}

We uncovered the prognostic values of peripheral CD8+CD28+ and CD8+CD28- T cells in advanced NSCLC patients treated with chemo(radio)therapy. High levels of peripheral CD8+CD28+ T cells showed favorable prognosis in ADs. Furthermore, increased levels of CD8+CD28- $T$ cells independently predicted poor survival in SCCs. ADs also had higher CD4+CD25 $\mathrm{T}$ cells and CD8+CD28- T cells and lower NK cells than SCCs. These results may help to identify advanced NSCLC patients with poor outcomes and refine treatment strategies.

\section{Supplementary information}

Supplementary information accompanies this paper at https://doi. org/10.1186/s12967-019-2097-7.

Additional file 1: Figure S1. Representative flow cytometry plots and gating. Figure S2. The distribution and median values of lymphocytes subsets in (A) 101 NSCLC patients, (B) 53 ADs, and (C) 48 SCCs. Figure S3. Comparing (A) OS and (B) PFS between high and low levels of B cells, NK cells, $\gamma \delta T$ cells, and NKT cells in 101 patients with advanced NSCLC. Figure S4. Comparing (A) OS and (B) PFS between high and low levels of B cells, NK cells, $\gamma \delta T$ cells, and NKT cells in 53 ADs. Figure S5. Comparing (A) OS and (B) PFS between high and low levels of B cells, NK cells, $\gamma \delta T$ cells, and NKT cells in 48 SCCs.

Additional file 2: Table S1. Demographics.

\section{Abbreviations}

PD-1: programmed death-1; AD: adenocarcinomas; OS: overall survival; SCC: squamous cell carcinoma; PFS: progression-free survival; NSCLC: non-small cell lung cancer. 


\section{Acknowledgements \\ Not applicable.}

\section{Authors' contributions}

$J M Y, H Z$, and $C L$ conceived and designed the study. CL, WJ, NA, AJL, and WWY collected clinicopathological data and blood samples. CL performed the experiments, statistical analysis, and wrote the manuscript. All authors read and approved the final manuscript.

\section{Funding}

This work was supported by the National Key Research and Development Program of China (No. 2018YFC1313201) and the Shandong Key Research and Development Program (No. 2016CYJS01A03).

\section{Availability of data and materials}

All data included in our study are shown in our manuscript.

\section{Ethics approval and consent to participate}

This investigation received approval from the Ethics Committee of the Affiliated Hospitals of Academy of Military Medical Sciences.

\section{Consent for publication}

All patients and healthy volunteers provided written informed consents.

\section{Competing interests}

The authors declare that they have no competing interests.

\section{Author details}

${ }^{1}$ Department of Oncology, Renmin Hospital of Wuhan University, Wuhan 430060, China. ${ }^{2}$ Department of Radiation Oncology, Shandong Cancer Hospital and Institute, Shandong First Medical University and Shandong Academy of Medical Sciences, Jinan 250117, Shandong, China. ${ }^{3}$ Department of Radiation Oncology, Affiliated Hospital of Academy of Military Medical Sciences, Beijing 100071, China. ${ }^{4}$ Weifang Medical University, Weifang 261053 , Shandong, China.

Received: 23 January 2019 Accepted: 11 October 2019

Published online: 17 October 2019

\section{References}

1. Siegel RL, Miller KD, Jemal A. Cancer statistics, 2019. CA Cancer J Clin. 2019:69:7-34.

2. Chen W, Zheng R, Baade PD, Zhang S, Zeng H, Bray F, et al. Cancer statistics in China, 2015. CA Cancer J Clin. 2016;66:115-32.

3. Tong YS, Tan J, Zhou XL, Song YQ, Song YJ. Systemic immune-inflammation index predicting chemoradiation resistance and poor outcome in patients with stage III non-small cell lung cancer. J Transl Med. 2017:15:221.

4. Yamamoto N, Nakagawa K, Nishimura Y, Tsujino K, Satouchi M, Kudo S, et al. Phase III study comparing second- and third-generation regimens with concurrent thoracic radiotherapy in patients with unresectable stage III non-small-cell lung cancer: West Japan Thoracic Oncology Group WJTOG0105. J Clin Oncol. 2010;28:3739-45.

5. von Verschuer U, Schnell R, Tessen HW, Eggert J, Binninger A, Spring $L$, et al. Treatment, outcome and quality of life of 1239 patients with advanced non-small cell lung cancer-final results from the prospective German TLK cohort study. Lung Cancer. 2017;112:216-24.

6. Kinoshita T, Muramatsu R, Fujita T, Nagumo H, Sakurai T, Noji S, et al. Prognostic value of tumor-infiltrating lymphocytes differs depending on histological type and smoking habit in completely resected nonsmall-cell lung cancer. Ann Oncol. 2016;27:2117-23.

7. Li Z, Maeda D, Yoshida M, Umakoshi M, Nanjo H, Shiraishi K, et al. The intratumoral distribution influences the prognostic impact of CD68and CD204- positive macrophages in non-small cell lung cancer. Lung Cancer. 2018;123:127-35.

8. Coco S, Alama A, Vanni I, Fontana V, Genova C, Dal Bello MG, et al. Circulating cell-free DNA and circulating tumor cells as prognostic and predictive biomarkers in advanced non-small cell lung cancer patients treated with first-line chemotherapy. Int J Mol Sci. 2017;18:1035.
9. Mo H, Hao X, Liu Y, Wang L, Hu X, Xu J, et al. A prognostic model for platinum-doublet as second-line chemotherapy in advanced nonsmall-cell lung cancer patients. Cancer Med. 2016;5:1116-24.

10. Kinoshita T, Fujii H, Hayashi Y, Kamiyama I, Ohtsuka T, Asamura H. Prognostic significance of hypoxic PET using (18)F-FAZA and (62)Cu-ATSM in non-small-cell lung cancer. Lung Cancer. 2016;91:56-66.

11. Saga T, Inubushi M, Koizumi M, Yoshikawa K, Zhang MR, Tanimoto K, et al. Prognostic value of (18) F-fluoroazomycin arabinoside PET/ $\mathrm{CT}$ in patients with advanced non-small-cell lung cancer. Cancer Sci. 2015; 106:1554-60.

12. Inagaki N, Kibata K, Tamaki T, Shimizu T, Nomura S. Prognostic impact of the mean platelet volume/platelet count ratio in terms of survival in advanced non-small cell lung cancer. Lung Cancer. 2014;83:97-101.

13. He YY, Zhang XC, Yang JJ, Niu FY, Zeng Z, Yan HH, et al. Prognostic significance of genotype and number of metastatic sites in advanced non-small-cell lung cancer. Clin Lung Cancer. 2014;15:441-7.

14. Chang CH, Hsiao CF, Yeh YM, Chang GC, Tsai YH, Chen YM, et al. Circulating interleukin-6 level is a prognostic marker for survival in advanced non-small cell lung cancer patients treated with chemotherapy. Int J Cancer. 2013:132:1977-85.

15. Leung EY, Scott HR, McMillan DC. Clinical utility of the pretreatment glasgow prognostic score in patients with advanced inoperable nonsmall cell lung cancer. J Thorac Oncol. 2012;7:655-62.

16. Sirera R, Bremnes RM, Cabrera A, Jantus-Lewintre E, Sanmartin E, Blasco $A$, et al. Circulating DNA is a useful prognostic factor in patients with advanced non-small cell lung cancer. J Thorac Oncol. 2011;6:286-90.

17. Yang $Y$, Wang M, Liu B. Exploring and comparing of the gene expression and methylation differences between lung adenocarcinoma and squamous cell carcinoma. J Cell Physiol. 2019;234:4454-9.

18. Li P, Zhang L, Yu X, Tong R, Di X, Mao Y, et al. Proliferation genes in lung development associated with the prognosis of lung adenocarcinoma but not squamous cell carcinoma. Cancer Sci. 2018;109:308-16.

19. Faruki H, Mayhew GM, Serody JS, Hayes DN, Perou CM, Lai-Goldman M. Lung adenocarcinoma and squamous cell carcinoma gene expression subtypes demonstrate significant differences in tumor immune landscape. J Thorac Oncol. 2017;12:943-53.

20. Kinoshita T, Ohtsuka T, Yotsukura M, Asakura K, Goto T, Kamiyama I, et al. Prognostic impact of preoperative tumor marker levels and lymphovascular invasion in pathological stage I adenocarcinoma and squamous cell carcinoma of the lung. J Thorac Oncol. 2015;10:619-28.

21. Usui S, Minami Y, Shiozawa T, lyama S, Satomi K, Sakashita S, et al. Differences in the prognostic implications of vascular invasion between lung adenocarcinoma and squamous cell carcinoma. Lung Cancer. 2013;82:407-12.

22. Sharpe AH, Pauken KE. The diverse functions of the PD1 inhibitory pathway. Nat Rev Immunol. 2018;18:153-67.

23. Bour-Jordan H, Blueston JA. CD28 function: a balance of costimulatory and regulatory signals. J Clin Immunol. 2002;22:1-7.

24. Weng NP, Akbar AN, Goronzy J. CD28(-) T cells: their role in the age-associated decline of immune function. Trends Immunol. 2009:30:306-12.

25. Rudd CE, Taylor A, Schneider H. CD28 and CTLA-4 coreceptor expression and signal transduction. Immunol Rev. 2009:229:12-26.

26. Liu C, Wu S, Meng X, Liu G, Chen D, Cong Y, et al. Predictive value of peripheral regulatory $T$ cells in non-small cell lung cancer patients undergoing radiotherapy. Oncotarget. 2017;8:43427-38.

27. Edge SB, Compton CC. The American Joint Committee on Cancer: the 7th edition of the AJCC cancer staging manual and the future of TNM. Ann Surg Oncol. 2010;17:1471-4.

28. Chen C, Chen D, Zhang Y, Chen Z, Zhu W, Zhang B, et al. Changes of CD4+CD25+FOXP3+ and CD8+CD28- regulatory T cells in non-small cell lung cancer patients undergoing surgery. Int Immunopharmacol. 2014;18:255-61.

29. Karagoz B, Bilgi O, Gumus M, Erikci AA, Sayan O, Turken O, et al. CD8+CD28 - cells and CD4+CD25+ regulatory T cells in the peripheral blood of advanced stage lung cancer patients. Med Oncol. 2010;27:29-33.

30. McCoy MJ, Nowak AK, van der Most RG, Dick IM, Lake RA. Peripheral CD8(+) T cell proliferation is prognostic for patients with advanced thoracic malignancies. Cancer Immunol Immunother. 2013;62:529-39. 
31. Muller P, Rothschild SI, Arnold W, Hirschmann P, Horvath L, Bubendorf $L$, et al. Metastatic spread in patients with non-small cell lung cancer is associated with a reduced density of tumor-infiltrating T cells. Cancer Immunol Immunother. 2016;65:1-11.

32. Petersen RP, Campa MJ, Sperlazza J, Conlon D, Joshi MB, Harpole $\mathrm{DH}$ Jr, et al. Tumor infiltrating Foxp3+ regulatory T-cells are associated with recurrence in pathologic stage I NSCLC patients. Cancer. 2006;107:2866-72.

33. Song G, Wang $X$, Jia J, Yuan Y, Wan F, Zhou X, et al. Elevated level of peripheral CD8(+)CD28(-) T lymphocytes are an independent predictor of progression-free survival in patients with metastatic breast cancer during the course of chemotherapy. Cancer Immunol Immunother. 2013:62:1123-30.

34. McCoy MJ, Lake RA, van der Most RG, Dick IM, Nowak AK. Post-chemotherapy T-cell recovery is a marker of improved survival in patients with advanced thoracic malignancies. Br J Cancer. 2012;107:1107-15.

35. Tokito T, Azuma K, Kawahara A, Ishii H, Yamada K, Matsuo N, et al. Predic tive relevance of PD-L1 expression combined with CD8+ TIL density in stage III non-small cell lung cancer patients receiving concurrent chemoradiotherapy. Eur J Cancer. 2016;55:7-14.

36. Toki MI, Mani N, Smithy JW, Liu Y, Altan M, Wasserman B et al. Immune marker profiling and PD-L1 expression across non-small cell lung cancer mutations. J Thorac Oncol. 2018;13:1884-96.

37. Kim H, Kwon HJ, Han YB, Park SY, Kim ES, Kim SH et al. Increased CD3+ T cells with a low FOXP3+/CD8+T cell ratio can predict anti-PD-1 therapeutic response in non-small cell lung cancer patients. Mod Pathol. 2019;32:367-75

38. Barua S, Fang P, Sharma A, Fujimoto J, Wistuba I, Rao AUK, et al. Spatial interaction of tumor cells and regulatory $T$ cells correlates with survival in non-small cell lung cancer. Lung Cancer. 2018;117:73-9.

39. Kinoshita T, Kudo-Saito C, Muramatsu R, Fujita T, Saito M, Nagumo H, et al. Determination of poor prognostic immune features of tumour microenvironment in non-smoking patients with lung adenocarcinoma. Eur J Cancer. 2017;86:15-27.

40. Schalper KA, Brown J, Carvajal-Hausdorf D, McLaughlin J, Velcheti V, Syrigos KN, et al. Objective measurement and clinical significance of TILs in non-small cell lung cancer. J Natl Cancer Inst. 2015;107:dju435.

41. Im SJ, Hashimoto M, Gerner MY, Lee J, Kissick HT, Burger MC, et al. Defining CD8+ T cells that provide the proliferative burst after PD-1 therapy. Nature. 2016;537:417-21.

42. Arens R, Loewendorf A, Redeker A, Sierro S, Boon L, Klenerman P, et al. Differential B7-CD28 costimulatory requirements for stable and inflationary mouse cytomegalovirus-specific memory CD8 T cell populations. J Immunol. 2011;186:3874-81.

43. Kamphorst AO, Wieland A, Nasti T, Yang S, Zhang R, Barber DL, et al. Rescue of exhausted CD8 T cells by PD-1-targeted therapies is CD28dependent. Science. 2017;355:1423-7.

44. Filaci G, Fenoglio D, Fravega M, Ansaldo G, Borgonovo G, Traverso P, et al. CD8+CD28 - T regulatory lymphocytes inhibiting T cell proliferative and cytotoxic functions infiltrate human cancers. J Immunol. 2007; 179:4323-34.

45. Orabona C, Grohmann U, Belladonna ML, Fallarino F, Vacca C, Bianchi R, et al. CD28 induces immunostimulatory signals in dendritic cells via CD80 and CD86. Nat Immunol. 2004;5:1134-42.

46. Jain N, Miu B, Jiang JK, McKinstry KK, Prince A, Swain SL, et al. CD28 and ITK signals regulate autoreactive T cell trafficking. Nat Med. 2013:19:1632-7.

\section{Publisher's Note}

Springer Nature remains neutral with regard to jurisdictional claims in published maps and institutional affiliations.
Ready to submit your research? Choose BMC and benefit from:

- fast, convenient online submission

- thorough peer review by experienced researchers in your field

- rapid publication on acceptance

- support for research data, including large and complex data types

- gold Open Access which fosters wider collaboration and increased citations

- maximum visibility for your research: over $100 \mathrm{M}$ website views per year

At BMC, research is always in progress.

Learn more biomedcentral.com/submissions 